\title{
Nigeria: A Country Profile
}

\author{
Emmanuel Ikechi Onah \\ Department of Political Science \\ University of Lagos \\ Nigeria
}

\section{Introduction}

Nigeria is a sovereign country located in the area of West Africa bordering on the Gulf of Guinea. The country has a total area of $923,769 \mathrm{sq} \mathrm{km}$ (a little more than twice the size of California). Its physical size makes Nigeria the third largest country in Sub-Saharan Africa. The country's terrain consists of the lowlands in the South with mountainous formations in the South-east, which merge into the hills and plateaus of the Central belt and the plains of the far north. The climate varies from the largely equatorial climates in the South to the tropical climates in the centre and the North (Ekoko, 1990). It is also the most populous country in Africa, with a population of about 160 million (2006 census), and a population growth rate estimate of $3 \%$. The country is bordered on the west by the Republic of Benin and the Republic of Cameroon, on the south by the Atlantic Ocean, and on the north by Niger Republic and the Republic of Chad. Nigeria is endowed with numerous natural resources, the most important being petroleum and natural gas, found in the Niger Delta areas of the country. Coal, iron ore, tin, limestone, zinc, lead, gold, precious stones, and uranium are found across the country.

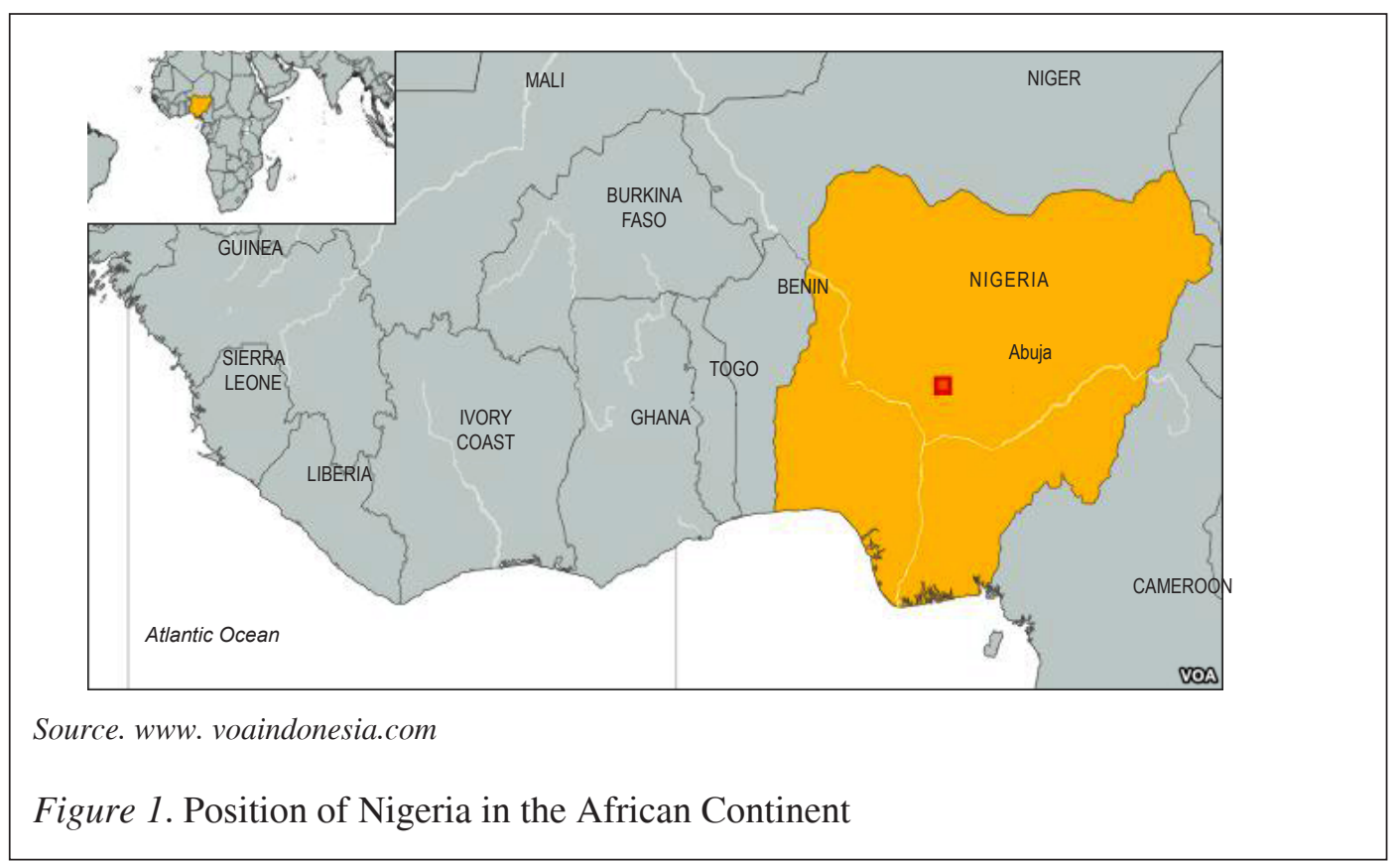


There are many ethnic groups, roughly categorized into the majority ethnic groups and the minority ethnic groups. The majority groups are namely, the Hausa-Fulani of the North, the Yoruba of the South-west, and the Igbo of the South-east. The hundreds of so-called minority ethnic groups include the Igala, Tiv, Idoma, Junkun, Angas, Birom and others in the Central-belt, the Edo, Urhobo and Itshekiri in the Mid-west, the Ijaw, Efik, Ibibio and Ogoni in the South-south, and the Kanuri, Gwari and Kataf of the far-North. On the whole, it is estimated that the country has more than 250 ethnic groups (Osaghae, 1998). English is the official language in Nigeria, by virtue of the country being a former colony of Britain. Christianity, Islam and traditional beliefs are the religions in the country, and although there is no state religion, the various tiers of government in the country are often involved in aspects of some of these religions, including state sponsorships of annual Muslim and Christian pilgrimages to the Holy lands.

\section{History}

Nigeria came into existence following the European conquest of territories during the scramble for Africa (Anene, 1970). As a result, the area of present day Nigeria fell to Britain. British conquest of the area followed three distinct directions, the western direction approximating to what became the colony of Lagos and the hinterland protectorate; the eastern direction that formed first, the Oil Rivers and later the Niger Delta protectorate; and the northern direction that became the Northern protectorate (Osaghae, 1998, p.4). In 1906, the Eastern and Western Protectorates and the Colony of Lagos were joined as the Colony and Protectorate of Southern Nigeria. Then, in 1914, the Colony and Protectorate of Southern Nigeria was amalgamated with the Protectorate of Northern Nigeria into the Colony and Protectorate of Nigeria. Nigeria's existence can thus be properly traced to 1914 . Between 1914 and 1920, Frederick Lugard, who hitherto was in charge of the North but was now placed in charge of the whole country after accomplishing the amalgamation, laid the ground rules of the administration of the territory. In 1916, he created the Nigerian Council, which served as advisory body to his government (Dudley, 1968).

In 1922, Hugh Clifford, who had earlier replaced Lugard as Governor of Nigeria, issued the first constitution for the territory. The Clifford Constitution of 1922 introduced the elective principle, limited to only Lagos and Calabar, and which allowed a restricted suffrage based on income qualifications (Nwosu, Olaniyi \& Oyedele, 1998, pp. 16-17). As a result of the elective principle, the first political party in the country was formed in 1923, named the Nigerian National Democratic Party (NNDP). The next Constitution was the Richards Constitution of 1946, which formally divided the territory into 3 Regions, namely the Northern, Western and Eastern Regions. The Macpherson Constitution of 1951 and the Lyttelton Constitution of 1954 further consolidated the move towards federalism. Multiparty elections were held in 1959 to usher the country into independence in 1960. The Northern People's Congress (NPC) won the elections in the Northern Region and had a majority at the Centre. The National Council of Nigerian Citizens (NCNC) won in the Eastern Region 
while the Action Group won in the Western Region. As no party won an absolute majority at the Centre, the NPC and the NCNC formed a coalition federal government while the AG became the Opposition party at the Centre.

The Independence Constitution of 1960 made Nigeria an independent nation within the British Commonwealth. The country practiced the parliamentary system of government, with the Prime Minister as the Head of Government. The British Monarch remained as the Sovereign, represented in Nigeria by the (ceremonial) President as Head of State. This changed with the enactment of the Republican Constitution of 1963 which made Nigeria a sovereign Republic (Post \& Vickers, 1973). In 1966 however, some military officers struck and deposed the democratic government. The coupists were largely Igbo officers of Eastern origin, and the high government officials that were killed were largely of Northern origin, including the Prime minister, Abubakar Tafawa Balewa, as well as the Premier of the Northern Region. The coupists actually failed in their mission of taking over the government, but the Nigerian Army nevertheless took power. The view then gained ground that the coup was an Igbo plot to remove the North from power, especially when the highest officer in the Nigeria Army at the time, General Aguiyi-Ironsi, who was Igbo, became Head of state.

Events soon degenerated, and in July 1966, the North carried out a counter-coup in which the Head of State was killed. Lt Col (later General) Yakubu Gowon, of northern origin, became Head of State. Soon, there was a massacre of Igbos living in the North, which then led to a largescale repatriation of Igbos from other parts of the country. Secessionist sentiments became rife within the Eastern Region and not long after, the Igbo Governor of the Eastern Region, Lt Col (later General) Odumegwu Ojukwu was mandated by a peoples' assembly to declare the Republic of Biafra (Kirk-Greene, 1971). A war then ensued between Biafra and Nigeria in July 1967, which lasted for about 3 years, ending in the defeat of Biafra in January 1970. General Gowon issued a policy of 'no victor, no vanquished', and the country moved back fairly together (Anifowose, 2006). General Gowon then promised a return to civil rule, but in 1975, it became obvious that he was going to renege on this promise. He was thereafter overthrown in a bloodless coup by General Murtala Mohammed.

General Mohammed promptly promised a return to civil rule in 1979, but he was soon killed in an abortive coup in 1976, and his second in-command, General Olusegun Obasanjo assumed position as Head of State. General Obasanjo inaugurated a transition programme and five political parties were allowed to canvas for votes. General Obasanjo eventually handed over power to the civilians in 1979, marking the beginning of the Second Republic. Alhaji Shehu Shagari of the National Party of Nigeria (NPN) became President. The NPN and the four other parties each controlled the government in a number of the then nineteen states of the Federation. The civilian regime was however, overthrown in a military coup at the very end of 1983 (Falola \& Ihonvbere, 1985). General Mohammadu Buhari became Head of State, but he himself was overthrown in another coup in 1985, and was replaced by General Ibrahim Babangida. General Babangida promised a return to civil rule, and 
inaugurated a transition programme in 1987 in this regard. The transition however, became long-winding and unending (Diamond, Kirk-Greene and Oyediran, 1997), and eventually collapsed in 1993 when the presidential election, meant to climax the Babangida transition programme, was annulled by government.

General Babangida eventually 'stepped aside', and was replaced by Chief Ernest Shonekan who headed a short-lived military-arranged Interim National Government (ING). In 1994, the ING was overthrown and a full-blown military government was instituted under General Sanni Abacha. General Abacha soon became a despot, and the country was once more moving steadily towards disintegration until the General suddenly died in 1998. General Abdulsalam Abubakar who replaced Abacha then inaugurated a transition programme that finally returned the country to civil rule in 1999, after multiparty general elections produced General Olusegun Obasanjo (now retired) as president, on the platform of the People's Democratic Party (PDP). The PDP has remained in power at the federal level and in most of the states of the federation ever since, with President Musa Yar A'dua emerging in the 2007 elections, to be replaced at his death in office, by his Vice President, Goodluck Jonathan. President Jonathan went on to win the 2011 general elections. New elections are scheduled in 2015.

\section{Administrative Set-Up}

Nigeria is a federal Republic. The Nigerian federation has three tiers, namely, the federal government, state governments, and local governments. All the tiers of government in the Nigerian federation are supposed to be independent and coordinate. The federation is made up of thirty-six states and seven hundred and seventy-four local government areas. There is also the Abuja Federal Capital Territory. The Nigerian Constitution has assigned responsibilities to each of these tiers of the federal structure. The Federal government has powers over all 68 items contained in the Exclusive Legislative List, including banking and currency, external relations, national security and police, customs and excise, immigration, airports and seaports. Apart from the Exclusive List, there is a Concurrent List, on which both the Federal government and the state governments can act. The Concurrent List contains 12 items, including revenue allocation, mineral oil and natural gas, taxes, elections, education and health. However, in the case of a clash between federal laws and state laws on any of the concurrent items, the former will prevail.

The states can also act on any other items that are residuary i.e not enumerated in the Exclusive or Concurrent Lists. In addition, the Fifth Schedule to the 1999 Constitution of the Federal Republic of Nigeria has enumerated eleven matters on which the Local Governments in the country can act. These local governments can also act on three other matters which are on the Concurrent List, namely agriculture, education and health. The laws of any state are however binding on every local government in that state (Onah, 2007, p.109). To enable the tiers carry out their responsibilities, the Constitution provides for the sharing of revenues 
accruing to the Nigerian federation among the three tiers of government through a revenue sharing formular. At present, the formular is $54.68 \%$ to the federal government, $24.72 \%$ to the states and $20.60 \%$ to the local governments (Aluko, 2004). The 1999 Constitution has further provided for $13 \%$ of revenues accruable to the federation from a given state of the country to be given to that state as derivation funds.

The present administrative set-up of the country derives from the 3-Region structure the country inherited at independence. Since then the structure has been adjusted continually until the present thirty six-state structure. These adjustments have followed widespread demands for the creation of more states and local government areas over the years. At the 1998 National Constitutional Conference, there was a new clamour for the grouping of states in the country along zonal lines. As a result, a new 6-zone structure was proposed in a new Constitution, to comprise of the North West, North East and North Central zones, the South West, South East and South South zones. Although this proposal was not put into constitutional effect eventually, the zones have nevertheless been invested with informal recognition, and have indeed become a central part of the geopolitics of the country and the basis on which political offices and government positions are shared out between the states and the local government areas.

\section{Political System}

Since 1979, Nigeria has practiced the presidential system of government. The 1979 Constitution (and the 1999 Constitution after it) replaced the parliamentary system that was practiced in the First Republic with the presidential system at the beginning of the Second Republic. The present Fourth Republic has continued with the presidential system. The Nigerian Constitution provides for three arms of government, namely, the executive, the legislature, and the judiciary. The executive arm is headed at the federal level by an executive president, who is elected every four years and with a provision for re-election for a second term. The President runs on the same ticket with the Vice-President, who acts on his behalf whenever the President is away from office and will take over if the President leaves office before the end of his tenure. At the level of the states, the constitution provides for an executive governor and a deputy governor, who also stay in office for four years at a time and for a maximum of eight years in that office. The president is the head of state as well as the head of government. He is also the head of the executive branch of government, and by this virtue, sits at the head of the federal cabinet of ministers who are appointed and removed at his pleasure.

The functions of the legislative arm are performed at the federal level by the National Assembly, consisting of the Senate and the House of Representatives. The National Assembly is empowered by the constitution to make laws for the peace, order and good government of the federation and on any matter included in the Exclusive and Concurrent Legislative Lists. 
The Senate is headed by the Senate President, while the House of Representatives is headed by the Speaker. The legislative power of any state of the Nigerian federation is vested in the House of Assembly of that state. The House of Assembly is headed by the Speaker. Each local government in the country has a Council where resolutions on issues concerning the local government area are usually deliberated upon and approved. The budgets of the local governments are however approved by the relevant state House of Assembly.

The third organ of government, the Judiciary, has the Chief Justice of the Federation at its head. In the states, the head of the judiciary is the Chief Judge. The structure of the Judiciary has the Supreme Court at the apex. This is the court of last resort as well as serves as the constitutional court of the country. It is followed by the Court of Appeal, which is itself structured according to judicial zones. Cases come up to this court from the High Courts. At the federal level, the Federal High Courts are courts of first instance, and have branches in every state of the federation. State High Courts are the highest courts in the judiciary of any state of the federation. The Federal High Courts can however, hear appeals from lower courts in a state. Appeals go from the federal and state high courts to the Court of Appeal. The state judiciary further consists of the Magistrate Courts and the Customary Courts which are the courts of first instance on customary issues in states with predominant Christian populations and people of other religions). In those states with predominant Muslim populations, it is the Sharia Courts that hear such cases in the first instance. Appeals go from the Customary and Sharia Courts to the Magistrate Courts, which are courts of first instance on civil matters. Appeals on customary or sharia matters could also go to the Customary or the Sharia Courts of Appeal as the case may be. These courts are on the same level with the High Courts, and appeals could go from them to the Federal Court of Appeal. Political parties have also been a feature of the political system in Nigeria, since 1923 when elections were first held in the country. The first political party to operate, the Nigerian National Democratic Party, was formed in 1923. At independence this party had ceased to exist, and instead, the parties that contested the independence elections of 1959 included, apart from the National Council of Nigerian Citizens (NCNC), Action Group (AG), and the Northern People's Congress (NPC), such other smaller parties as United Middle Belt Congress (UMBC), Bornu Youth Movement (BYM), and United National Independents Party (UNIP) (Sklar, 1983). The Nigerian Army eventually toppled the First Republic in 1996 when they staged a coup and later, a counter coup. Although the military government disbanded political parties and outlawed their activities, the nature, character and outlook of the first Republic parties have continued to define the political parties that have been set up in subsequent Republics (Agbaje \& Adejumobi 2006).

A typology of these parties can even be made, with all the Republics featuring parties that can be grouped into what is often called Conservative parties and Progressive parties. The conservative parties would refer to all the parties that have tended to promote the status quo in Nigeria, while the progressive parties have claimed to pursue change in the way that things are done in the country. Among the big parties of the First Republic, the NPC was clearly the bastion of conservatism, while the AG represented the progressive tendency. In 
1979, new parties emerged when the military decided to hand power back to civilians, but these parties were disbanded once more when the military again stuck in 1983 and took back power. In 1999 however, they handed over again to civilians. In the present Fourth Republic, the parties have been more fluid and it is very difficult to make a clear distinction between them. Although the various parties of the Fourth Republic have laid claims to ideological tendencies, the parties have in reality, shown more ideological similarities and behavioural sameness than in any other Republic in the country's history.

\section{Economy}

Nigeria had a large agriculture-based economy at independence, with a vast amount of arable land. Food crops were produced in large quantities in the North and transported to the South to serve the rest of the country, which largely practiced subsistence agriculture. The food crops included corn, rice, sorghum, millet, cassava and yam. In addition, livestock, particularly cattle, sheep and goat were also obtained in the North from where the rest of the country was supplied. The then 3 Regions were at the time also known for the cultivation of specific cash crops. The East was known for palm produce, including palm oil, while the West was known for cocoa and rubber production. The North produced peanuts and was indeed world famous for its groundnut pyramids. Industrial development was low all through the early years of independence, and largely because of this, agriculture was not given the push and synergy that would have enabled country to move on the path of sustainable growth.

The story is always told in Nigeria of how Malaysia and some other South-East Asian countries obtained their first palm nut seeds from Nigeria, only to overtake the country in palm produce a few years after. Nigeria presently imports palm products from the South-East Asian countries. Nonetheless, a few industries sprang up early in the country, especially for the purposes of extracting and exploiting the numerous natural resources that abound in Nigeria. Unfortunately, the road to industrialization was truncated when Nigeria started commercial exploitation of oil in the early 1970's. Within a few years of this, agriculture and agriculture-based industry dipped in the country's economic reckoning, and oil became the country's major revenue earner. By the middle 1970s, the proportion of oil earnings to total revenues was more than $75 \%$ (Nwankwo, 1983, p.17), and by the 1990s, this had climbed even further.

This situation eventually boomeranged in the late 1980s when the price of oil fell in the international market. The country then acquired a huge debt profile, and attempts at structural adjustment, not only led to widespread riots in1987, but ultimately proved unsuccessful (Yesufu, 1996). Instead, corruption became permissive and poverty and disease became widespread. All these were compounded by long years of military rule which only came to an end in 1999. The new civilian regime that succeeded military rule almost immediately, embarked on efforts aimed at bringing the country back on its footing. A major plank of 
this rebuilding effort was the adoption of a new economic policy of liberalization, from around 2004, involving deregulation, privatization and commercialization. Government participation in the economy was then drastically reduced. Civil servants had a number of privileges monetized, and government contracts were subjected to new due process procedures. Government owned companies and properties were sold openly as a means of raising revenues or conserving government funds, and reducing waste. Then, other government enterprises were commercialized (Maduabum, 2006).

Reforms, coupled with increased prices for crude oil in the international markets, have induced the Nigerian economy to record a steady growth at an estimated rate of $6.2 \%$ annually. Economic growth has however not translated into reduction of poverty, which levels has also grown in recent times, with $70 \%$ of the population living below the poverty line in spite of the huge revenues steadily accruing to the country (CIA World Factbook, 2013). Nor has increased emphasis on due process, transparency and accountability reduced corruption in any considerable way. This cankerworm has now permeated every aspect of the country's life, and Transparency International has consistently rated Nigeria among the Most Corrupt Nations in the world (TI, 2012). In April 2014, Nigeria carried out a rebasing of her economy. This put the country's gross domestic product (GDP) at a 2013 estimate of US\$502 billion, making Nigeria the biggest economy in Africa (CIA World Factbook, 2013).

\section{Foreign Relations}

At independence in 1960, Nigeria belonged to a bloc of countries in Africa whose foreign policies were conservative and pro-western. Nigeria had actually announced at the time that her foreign policy would be non-aligned as well as have Africa as its centre-piece (Sesay et al. 2011., p.18). But in reality, Nigeria's foreign policy was almost tied to the apron-strings of Great Britain, her erstwhile colonial master. Shortly afterwards, protests by university students led to the abrogation of a military pact that would have entailed Britain maintaining military bases in Nigeria. When the civil war with Biafra started in 1967, Britain was prominently behind Nigeria, which it wanted to survive as evidence of the success of British colonial policy in Africa. Interestingly, both the USA and the then Soviet Union (USSR) also lined up behind Nigeria in the war. After the war, the USSR was rewarded for her support with lucrative steel sector contracts, but Nigerian foreign policy continued to be pro-western and conservative. The military government of General Gowon was particularly pro-British, and the country's growing oil industry was consequently dominated by British interests.

In 1975, General Gowon was overthrown and was succeeded by General Murtala Mohammed. Almost immediately, the Mohammed regime pledged to continue with the policy of non- alignment. He also announced that Africa would remain the centre piece of Nigeria's foreign policy. In pursuit of this Africa-centredness, General Mohammed 
made a commitment to support the struggle to liberate all of Africa still under colonial or apartheid rule. This policy was eventually to bring Nigeria in confrontation with Britain and other Western powers, when the country championed an African resolve to support the socialist Popular Movement for the Liberation of Angola (MPLA) in the fight for Angola's independence (Sesay et al., 2011). General Mohammed was killed shortly after this in the abortive coup of February 1976, but General Obasanjo who succeeded him continued with the Africa-centred foreign policy.

Nigeria continued to be a strong member of the Organization of African Unity (OAU), now the Africa Union (AU). To show her unhappiness with British support for Apartheid South Africa, the Obasanjo regime nationalized a number of British business interests in Nigeria. Fuelled by enormous receipts from oil sales, needy African countries received generous help in monetary and technical aids. In recent years, Nigeria has set up a Technical Aid Corps, which sends young professional Nigerians to needy African countries to help with the development of these countries. In recognition of Nigeria's contributions to African liberation, she was made an honorary member of the Frontline States, comprising of countries that were supposed to have borne the brunt of the anti-apartheid struggle. This was among other honours, which included being made the permanent chair of the United Nations Committee against Apartheid. Nigeria has since repaired her relations with the West.

Following a downturn in the country's economy in the 1980s and 1990s, there has been a somewhat reduction in Nigeria's generosity towards her African neighbours. Nevertheless, Africa has remained the centre-piece of Nigeria's foreign policy and economic downturn has not affected Nigeria's commitment to the international organizations that she belongs to, particularly her contributions to international peace keeping efforts. Shortly after independence, Nigerian troops were sent as part of the United Nations Peacekeeping Mission to the Congo. Between 1960 and date, Nigeria has participated in several such peacekeeping efforts, including in Lebanon, Yugoslavia, Somalia, Rwanda, Chad, Liberia and Sierra Leone (Akinboye, 2003, p. 53).

Nigeria's commitment to world peace has also been exemplified by her roles in the various conflicts that have plagued West Africa. Nigeria was at the forefront of the formation of the Economic Community of West African States (ECOWAS). The primary aim of ECOWAS was economic integration, but when in the late 1980s and early 1990s, war broke out, first in Liberia and later in Sierra Leone, Nigeria was again instrumental in amending the provisions of the ECOWAS Charter to enable the Organization intervene in the conflicts. The country then bore the major responsibilities and costs of the peace efforts in those countries until the United Nations came in, much later on. The country has been similarly involved in other conflict resolution efforts in West Africa and the entire continent.

Economic downturn ultimately necessitated a new thrust in Nigeria's foreign policy that emphasized economic diplomacy (Saliu, 2006). This has encouraged Nigeria to diversify 
her international economic relations. At independence, the country's major trading partners were Great Britain, USA and other western countries. This pattern continued for a long time except for the brief period of the country's civil war when considerable trade relations existed with the then Soviet Union. Gradually however, the situation has been changing, and apart from the West, Asian countries have become important trade partners of Nigeria. In fact, China has become a big player in the Nigerian economy, and is now among the country's top 3 trading partners. Japan and India are also important in this regard. Apart from these countries, others, such as Malaysia, have also increased the volume of their trade with the country, and Nigeria now imports such agricultural goods as rice and vegetable oil from Malaysia. Malaysia and other South-East Asian countries are also participating in other sectors of the Nigerian economy, including oil and gas, telecommunications, construction, shipping and pharmaceuticals.

\section{Nigeria at a Glance}

Capital city: Abuja

Nationality: Nigerian (s)

Type of Government: Federal Republic

National holidays: Independence Day (October 1); Democracy Day (May 29)

Population: 160 million (2006 population census)

Population growth rate: $3 \%$ (2006 estimate)

Size: 923, 769 sq km (slightly more than twice the size of California)

Major Ethnic groups: Hausa-Fulani, Yoruba, Igbo

Religions: Christianity, Islam, Traditional Beliefs

Languages: English (official), Hausa, Yoruba, Igbo

Gross Domestic Product: US\$502 billion (2013 estimate)

GDP growth rate: $6.2 \%$ (2013 estimate)

Administrative divisions: 774 local government areas, 36 states, 1 Federal Capital

Territory

Major Political Parties: Peoples Democratic Party (PDP), All Progressives Party (APC)

Source: CIA World Factbook

\section{References}

Agbaje, A., \& Adejumobi, S. (2006). Do votes count? The travails of electoral politics in Nigeria. Africa Development, XXXI(3), 25-44.

Aluko, E. M. (2004, November). Brief historical outline of revenue allocation formulas in Nigeria. Retrieved from http://www.nigerianmuse.com/important_documents/? 
Akinboye, S. O. (2003). Nigeria's peacekeeping mission in West Africa: Lessons for South Africa in Southern Africa. International Review of Politics and Development, 1(1), $51-65$.

Anene, J.C. (1970). The international boundaries of Nigeria, 1885-1960: The framework of an emergent African state. London: Longman.

Anifowose, R. (2006). Violence and politics in Nigeria: The Tiv and Yoruba experience. Lagos: First Academic Publishers.

CIA World Factbook. (2013). Retrieved from http://www.cia.gov/library/publications/theworld-factbook/geos/ni.html

Diamond, L., Kirk-Greene, A., \& Oyediran, O. (Eds.) (1997). Transition without end. Ibadan: Vantage Publishers.

Dudley B. J. (1968). Parties and politics in Northern Nigeria. London: Frank Cass.

Ekoko, A. E. (1990). The historical and socio-political environment of Nigerian defence policy. In A. E. Ekoko, \& M. A. Vogt. (Eds.). Nigerian defence policy: Issues and problems. Lagos: Malthouse press.

Falola, T., \& Ihonvbere, J. (1985). The rise and fall of Nigeria's Second Republic, 1979-84. London: Zed.

Kirk-Greene A. H. M. (1971). Crisis and conflict in Nigeria. Vols. 1\&11. London: OUP.

Maduabum, C. (2006). Reforming government bureaucracies in Nigeria: The journey so far. Lagos: ASCON Press.

Nwankwo, G. O. (1983). Nigeria and OPEC: To be or not to be. Ibadan: AIP Press.

Nwosu, N. I., Olaniyi, J. O., \& Oyedele, S. O. (1998). Introduction to constitutional development in Nigeria. Ibadan: SUNAD Publishers.

Onah, E. I. (2007). Fiscal arrangements and inter-governmental relations in three federations: Nigeria, Pakistan and Canada. Nigerian Journal of International Affairs, 33(2), 101119.

Osaghae, E. E. (1998). Crippled giant: Nigeria since independence. Bloomington: Indiana University Press.

Post, K. W. J., \& Vickers, M. (1973). Structure and conflict in Nigeria: 1960-1965. London: Heinemann. 
Saliu, H. A. (2006). Attraction of economic investment under economic diplomacy. In H. A. Saliu. Essays on contemporary Nigerian foreign policy, Vol. 11. Ibadan: Vantage Publishers.

Saliu, H. A. (2006). Nigeria's participation in peace-keeping operations: Matters Arising. In Saliu, H. A. Essays on contemporary Nigerian foreign policy, Vol. 11. Ibadan: Vantage Publishers.

Sesay, A., Fawole, W. A., Adetula, V. A. O., Asiwaju, A., \& Rimdap, A. B. (2011). Reflections on Nigeria's foreign policy. Lagos: Society for international relations awareness \& Friedrich Ebert Stiftung.

Sklar, R. L. (1983). Nigerian political parties: Power in an emergent African nation. Enugu: NOK.

Transparency International. (2014). Corruption perceptions index (several years). Retrieved from http://archive transperency.org/policy-research/survey-indices/cpi/

Yesufu, T. M. (1996). The Nigerian economy: Growth without development. Benin: The Benin Social Science Series for Africa. 